Dialectologia 24 (2020), 273-296.

ISSN: 2013-2247

Received 20 February 2018.

Accepted 4 May 2018.

\title{
IDENTITY AND DISCURSIVE PRACTICES OF FRIULIANS AND SLOVENES IN THE PROVINCE OF UDINE, ITALY, IN RECENT DECADES
}

\author{
Danila ZULAN KUMAR \\ Institute of Slovenian Language Fran Ramovš / Research Centre of Slovenian Academy of \\ Sciences and Arts* \\ DZuljan@zrc-sazu.si
}

\begin{abstract}
In the past, Slovene spoken in the Province of Udine and Friulian, mainly spoken in the Provinces Udine, Pordenone and Gorizia of Friuli-Venezia Giulia, Italy, were limited to the private sphere, but recently, they are becoming more seen and heard in public life, i.e. outside their traditional communication situations. The change can be attributed to the changes in the perception of their mother tongue in the Slovene and Friulian communities themselves in relation to the prevailing Italian language, the use of which implied a more prestigious position in society in the past, as well as to the change of attitudes towards the two minority languages among the majority population. Changes of discursive practices are occurring hand in hand with changes in identity practices. The paper presents a qualitative study on the topic in which 22 sociolinguistic interviews with the speakers of Friulian and the Slovene were carried out.
\end{abstract}

\section{Keywords}

Slovenes in the province of Udine, Friulians, discursive practices, identity practices

\footnotetext{
* Research Centre of Slovenian Academy of Sciences and Arts, Intitute of Slovenian Language Fran Ramovš, Novi trg 2-4, 1000 Ljubljana, Slovenia.
} 


\section{IDENTIDAD Y PRÁCTICAS DISCURSIVAS DE FRIULANOS Y ESLOVENOS EN LA PROVINCIA DE UDINE, ITALIA, EN DÉCADAS RECIENTES}

\section{Resumen}

En el pasado, el esloveno hablado en la provincia de Udine y el friulano, principalmente hablado en las provincias de Udine, Pordenone y Gorizia de Friul-Venecia Julia, Italia, se limitaba a la esfera privada, pero recientemente, son más vistos y escuchados en la vida pública, es decir, fuera de sus situaciones de comunicación tradicionales. El cambio puede atribuirse a las modificaciones en la percepción de su lengua materna en las propias comunidades eslovena y friulana en relación con el idioma italiano predominante, cuyo uso implicaba una posición más prestigiosa en la sociedad en el pasado, así como al cambio de actitudes hacia las dos lenguas minoritarias entre la población mayoritaria. Los cambios en las prácticas discursivas están ocurriendo conjuntamente con los cambios en las prácticas de identidad. El artículo presenta un estudio cualitativo sobre el tema en el que se realizaron 22 entrevistas sociolingüísticas a los hablantes de friulano y esloveno.

\section{Palabras clave}

eslovenos en la provincia de Udine, friulanos, prácticas discursivas, prácticas de identidad

\section{The Autonomous Region of Friuli-Venezia Giulia, Italy and its linguistic and cultural heterogeneity}

The salient feature of Friuli-Venezia Giulia (hereafter FVG) is its cultural and linguistic heterogeneity. Beside three indigenous historical linguistic minorities, i.e. Friulian, Slovenian and German, which enjoy a certain minority protection, there exist the Serbian, Croatian and Jewish historical communities, which were established in FVG during economic migrations in the period of Austro-Hungarian Empire, and many new communities formed by immigrants from Eastern Europe, Asia and Africa in the recent decades (Vidau 2013: 28-29). Friulians live in the provinces of Udine, Gorizia and Pordenone ${ }^{1}$ and outside FVG in the area of Portogruaro which belongs to the Veneto region, the German speaking population lives only in the province of Udine, while the

\footnotetext{
${ }^{1}$ Before it was completely replaced by the present Venetian dialect, Friulian variety also used to be spoken in the Province of Trieste (Coluzzi 2007: 170; Heinemann 2015: 226).
} 
Slovenes live in the provinces of Udine, Trieste and Gorizia. Friulian language is recognized in 177 municipalities of 221 altogether, which presents $80 \%$ of all FVG's municipalities, Slovenian language is recognized in 32 municipalities $114 \%$ of all municipalities) and German language is recognized in 5 municipalities (2\% of all municipalities). 200 municipalities in FVG (90\% of altogether) have at least one of the recognized minority group (Vidau 2013: 33).

\section{The social position of Friulians and the Slovenes living in the Province of Udine}

The members of the Slovenian ethnic minority in Italy did not have the equal legal status in the three provinces of FVG until 2001. Slovenes, living in the Provinces of Trieste and Gorizia have enjoyed a certain minority protection since $1954,{ }^{2}$ compared to that of South Tiroleans, while the Slovenes living in the Province of Udine ${ }^{3}$ were not granted the status of a historic linguistic minority until the Law n. 38 entitled "Norme a tutela della minoranza linguistica slovena della regione Friuli - Venezia Giuli" (Regulations for the protection of the Slovene linguistic minority in Friuli - Venezia Giulia) was passed in the Italian Parliament in 2001. It enhanced and systematized the previous protection and extended it to the whole Slovene linguistic minority in FVG.

The Friulian linguistic community was officially recognized by the Regional Law $n$. 15, adopted in 1996. That was the first legislative norm that recognized Friulian as a language and explicitly provided the possibility for local authorities to use it in their meetings, in toponymy and in general for their communication with citizens (Cisilino 2014: 17). With the Law n. 482/1999 entitled "Norme in materia di tutela delle minoranze linguistiche storiche" (Law governing the protection of historical linguistic minorities))

\footnotetext{
2 The Memorandum of Understanding signed in London on the $26^{\text {th }}$ October 1954 defined a detailed language regime and provided for complete equality of treatment of the "Yugoslav ethnic group" in the Italian-administered area and the "Italian ethnic group" in the Yugoslav-administered area. It stipulated for equal linguistic rights concerning the press, educational, cultural, social and sports organisations. There was also the obligation that signs and place names should be equally in the language of the minority group, where the latter constituted a significant element (at least one quarter) of the population.

${ }^{3}$ In the Province of Udine Slovenes live in the three areas: Beneška Slovenija/Slavia Veneta, Kanalska dolina/Val Canale and Rezija/Val Resia.
} 
Friulians together with other indigenous historical linguistic minorities in Italy, i.e. Albanian, Catalan, German, Greek, Slovene, Croatian, French, Franco-Provençal, Ladin, Occitan and Sardinian, acquired the status of a regional language providing for its use in the school system, public administration, public media, and the regional parliament (Cisilino 2014: 16). ${ }^{4}$

This article focuses on the Friulian community and that part of the Slovenian community that lives in the so-called Beneška Slovenija/Slavia Veneta, the Province of Udine, which had to face much harder conditions of survival, compared to the Slovenes living in other two provinces. In the past, Friulian and Slovene spoken in the Province of Udine were limited only to the private sphere, to the use in family, within Slovenian and Friulian institutions and not in official dealings. Today they are also becoming heard and seen outside these frames, i.e. in Italian public life. This is the result in part of the changes in the attitude of the authorities towards both ethnic communities as a consequence of broader social changes in relation to minority and regional languages in Europe (promotion of principles of multilingualism and multiculturalism according to which the above mentioned legislation for the protection of indigenous historical linguistic minorities was adopted $)^{5}$ and in part of a successful model of schooling in the Slovenian community in lower and middle bilingual school in Špeter/San Pietro al Natisone ${ }^{6}$ whereas Friulian in recent years has been gradually introduced as a subject of study in primary schools. The introduction of these languages in schools has contributed to a gradual change in the attitude of speakers of these languages to their mother tongue, by means of which their awareness is reinforced that the regional language is one of the pillars for preserving differences among regions and that its use represents a strong

\footnotetext{
${ }^{4}$ According to the traditional classification of minority languages in Italy Friulian is ranked as the language of a linguistic minority, which means that its speakers are bearers of Italian culture and identity, who use particular linguistic varieties, while Slovene is ranked as the language of a national minority (lannàccaro \& Dell'Aquila 2015: 454). However, the Law 38/2001 uses only the term linguistic minority (Zaščitni zakon za Slovence v Italiji 2001). The European Charter for Regional and Minority Languages, on the other hand, uses the terms regional and minority languages referring to "languages traditionally used within a given territory of a state by nationals of that state who form a group numerically smaller than the rest of the state's population; they are different from the official language(s) of that state, and they include neither dialects of the official language(s) of the state nor the languages of migrants". <https://www.coe.int/en/web/european-charter-regional-or-minority-languages/languages-covered. Neither of the legal acts uses the term ethnic or national minority.

${ }^{5}$ On the revival of Friulian today see also Vidau (2013: 33), Coluzzi (2015: 508) and Melchior (2015: 3).

${ }^{6}$ The centre of Slovenes living in Beneška Slovenija/Slavia Veneta.
} 
indicator of the belonging to the community and reflects the speaker's regional and local consciousness (Vassberg 1993: 158).

A third crucial factor facilitating the validation of regional languages is globalization. This has triggered the process of a deepened awareness of belonging to a narrow, local and regional space that includes the (re)awakening of local and regional cultural heritage practices (Fakin Bakec 2016: 22), which Beck calls relocalization (Beck 2003) and which Fishman illustrates with the idea that

Some of the very processes of globalization and post-modernism that were supposed to be most deleterious to purportedly "parochial" identities have actually contributed most to their re-emergence [...] (Fishman 2001: 460).

Changes in the perception of their own language in relation to the Italian language that dominates in all spheres of life among Friulians and Slovenes in the Province of Udine can thus be placed within a wider European context of regionalization and decentralization which with changing discursive practices among speakers also brings with it changes in identity practices.

\section{The relationship between discursive and identity practices}

This article focuses primarily on identity practices connected with the individual or group's ethnic belonging. Ethnic identity as a collective identity - whose basis is the relationship that the individual has established towards a specific community that is aware of its existence particularly in a territorial, biological-genetic, and linguistic-cultural sense (Šabec 2006: 152) - represents an important part of human experience. Within this framework we are interested in particular in the psychological aspect of ethnic belonging, since this investigates the connection between the individual's belonging to an ethnic group and their acceptance or rejection of being recognized as a member of this group, 
but it is interesting that this is a relatively new research field for psychologists (Padilla \& Borsato 2010: 11).

Most people begin to identify with an ethnic community in the process of primary socialization that takes place through language, which means that language is a crucial factor in the individual's identity. An individual expresses their identity through their own discursive practice, in which their speech acts are in fact projections with which they create models of discourse that are the same as or similar to models of the group they wish to belong to (or differ from it). In comparison with Howard Giles, who in his Communication Accommodation Theory (CAT) claims that a speaker through their choice of idiom in a speech situation accommodates other speakers, Le Page \& Tabouret-Keller find that a speaker in fact accommodates the image that they have of themselves in relation to the person they are talking with (Le Page \& Tabouret-Keller 1985: 181). Thus, if a speaker perceives their idiom as subordinated to their interlocutor, they perceive their position in society as subordinate to that of their interlocutor's. Language transcends its role as a means of communication and represents a strong semiotic and symbolic tool as well (García 2010: 520), as a result of which the speaker in a multilingual community pragmatically chooses discursive practices depending on who they wish to be (Heller 1999). Their choice is influenced by a number of factors, the three most important being: the attitude of the family towards the mother tongue, the attitude of the majority population towards this language, and the individual's feeling of belonging to the language group (Vassberg 1993: 5). The attitude of the family towards the mother tongue is of crucial importance, since the child in the process of socialization along with learning the language also adopts the attitude towards it while at the same time adopting the cultural values of parents and the community in which the child lives through cultural practices, by means of which language becomes associated with an emotional dimension (Padilla \& Borsato 2010: 12-13) that influences his loyalty to the community. The attitude of the dominant social group towards the minority/regional language is also important. If the language that the child speaks has the status of an inferior language in the dominant social group, then the child understands this to mean that they are a member of a group whose language and culture in the eyes of the dominant and more powerful social group are not respected (García 2010: 12). Also important is the fact that changed social 
conditions, in which the use of a particular language becomes acceptable and even treated as a value, significantly influences the attitude towards the language of speakers themselves, which brings with it changes in the identification of the individual and group. Studies have shown that identity is not "an unchanging warehouse of features, images and customs" (Preston 1997: 4) but rather a constantly developing response to the development of society (Harvey 2001: 211).

\section{The study. Reasons, goals, and choice of methodology}

There are two reasons that prompted my interest and inquiry into the discursive and identity practices of Friulians and Slovenes in Beneška Slovenija/Slavia Veneta. First, there is an increasing number of works on the topic published in the last two decades. ${ }^{7}$ Second, I myself as a researcher and regular visitor of the area can also see the increasingly stronger presence of Slovene and Friulian in public places and in formal or semiformal communication situations, ${ }^{8}$ which clearly indicates changes in the discursive practices of Slovenes and Friulians.

\footnotetext{
${ }^{7}$ The connection between Friulian language, Friulian identity and the cultural rights of the Friulian community have been thematised in works by by Žabjek-Scuteri (1987), Strassoldo (1996), Roseano (1999, 2002), Cisilino (2001, 2008, 2014, 2015), D’Aronco \& Cisilino (2012), Picco (2008, 2013, 2014), Coluzzi (2007, 2015), Iannàccaro \& Dell'Aquila (2015), Melchior (2015), Stolfo \& Cressati (2016), and the connection between Slovene language and Slovene identity in the Slovene community in Italy (especially in the Province of Udine) by Zuljan Kumar (2011, 2016, 2018), Colja (2013), Pertot \& Kosič (2014) Vidau, (2015a, b), Steinicke et al. (2016), Mezgec, (2016). The identities of ethnic or linguistic minorities in FVG and in Italy in general have been treated, for example, by Bonamore (2004), Coluzzi (2007), Susič, Janežič \& Medeot (2010) and Vidau $(2012,2013,2015 a, b)$. There has also been noticed an increasing interest of researchers in minority language as economic resource and its potentials for the development of the region. See for example Strassoldo (2002), Marangon (2002), Rosa (2002), Possenti (2002), Sillani (2002), Stolfo (2014), Duca (2014) and Finco (2014) for the Friulian language and Quaglia (2014) and Dapit (2014) for the Slovene language in the Province of Udine.

${ }^{8}$ The accuracy of my observations has been confirmed by the findings of the survey on the Friulian habits, attitudes, opinions, knowledge and use carried out by The Department of Human Sciences (University of Udine) in 2013-2014 and published in 2015 which points out that Friulian language is

experiencing a phase of "cultural rebound" and profound changes. /.../ The loss over time of the number of speakers has scaled down compared to what occurred until 2000. In the last decades of the 20th century, Friulian was "fading" with a rate of about $1 \%$ of speakers lost per year, as parents stopped teaching the language to their children starting with the '60s. Today, this loss rate is at $0.6 \%$ per year, and tends to decrease over time.
} 
In order to determine the causes for these changes a qualitative study between 2012 and 2015 was conducted in which 22 sociolinguistic interviews in a heterogeneous age group (from 25 to 76 years) with questions prepared in advance were carried out. All the interviews were conducted with members of the Slovenian minority (i.e. 11) at the main office of Inštitut za slovensko kulturo/ the Institute for Slovenian Culture in Špeter/San Pietro al Natisone and at the main office of Kulturno društvo Ivan Trinko/the Ivan Trinko Cultural Society in Cividale del Friuli. Three interviews with Friulian speakers I wre also carried out at the main office of Societât Filologjiche Furlane/Friulian Philological Society in Gorizia, at the headquarters of ARLeF (Agjenzie regjonâl de lenghe furlane/Agency for the Promotion of Friulian Language) in Udine and with a relative in Cormons, ${ }^{9}$ and the rest were conducted by a student, Vlasta Križman, as part of her research for her graduation thesis. The questions put to our informants were as follows:

a) What defines you as a Slovene/Friulian? Is language in your opinion the most important signifier of your Slovenian/Friulian identity?

b) In which (social) group in your opinion is Slovenian/Friulian identity most strongly expressed and Slovene/Friulian language most in use?

c) Which language/languages do you use in your family?

d) What in your opinion is the difference between the expression of Slovenian/Friulian identity in the past and today?

e) How do you see the future of the community to which you belong?

By contrast, a new and extremely interesting phenomenon is emerging: young people under thirty actively speak Friulian more than those in their thirties and forties, who are quite close to the former, age-wise.

This "rebound" is a solid fact. In addition to our research, in fact, the phenomenon has emerged in other recent studies, and is consistent with the observation of society, the territory, the cultural events that take place there and their turnout. This seems to be the most obvious sign, but not the only one, of a turning point and a profound change in the very meaning of speaking in Friulian, which opens the doors to a future with very different prospects compared to past predictions (Melchior 2015: 1).

${ }^{9}$ I would like to thank all the informants who kindly responded to the invitation to participate. At the end of the article I list only those informants whose statements are quoted in the text as sources, identified by their initials. 


\section{Results and discussion}

5.1 What defines you as a Slovene/Friulian? Is language in your opinion the most important signifier of your Slovenian/Friulian identity?

It was assumed that the answer to the question of what defines someone as a Slovene/Friulian would be mainly language and this was in fact the case in some responses: "I think that being Slovene is tied very much to living in this territory. And what distinguishes us from Friulians is language, right?" (NM). However, the response of a Friulian: "For me being Friulian means the possibility to express myself through the knowledge and culture of my people" in addition to a common language implicates the feeling of belonging to an ethnic group that speaks Slovene/Friulian, as indicated by the majority of responses, such as for example the following:

Clearly it is primarily the language, since one is accustomed to speaking in one's own language from childhood; this I think is the most important characteristic that makes you a Slovene in this space. But then there are others. Here there are other everyday things that, when you come into contact with another reality, as Friuli is for us, you realize that there are differences relating to traditions, relating to customs. (DC)

5.2 In which (social) group in your opinion is Slovenian/Friulian identity most strongly expressed and Slovene/Friulian language most in use?

Slovene speakers showed large differences in their response to this question depending on their age. Some older speakers were of the opinion that there are no essential differences in belonging to "Slovenian things" in the past and today, but that due to more favorable social conditions the expression of Slovenian identity in the Italian space has become more open and is not just confined to life within the community.

In my opinion the feeling of identity in the past was very strong but it wasn't expressed due to pressure and opposition. Today there are far fewer problems and 
so people are not afraid. For example school, today there are a hundred or so pupils at bilingual schools and they also come from mixed marriages and even from Italian families, the school is attractive to them. It was not easy in the beginning to show oneself. In my view now it has become more widespread, I don't know why, because there's no longer pressure, we're stronger, the borders have fallen, I don't know, different reasons. (NM)

The views of younger speakers differed. A significant difference in a feeling of belonging to the Slovenian community can be seen in the awareness of this belonging that younger generations who have attended the bilingual school in Špeter/San Pietro al Natisone have, since "they taught us in school that something is identity, something is citizenship", while older generations in many cases do not, or as one member of the younger generation put it by way of illustration:

Language among older people is definitely stronger and this definitely unites them but that older people are more conscious than younger, I think not, not in general, since if you were to ask my grandmother she would probably say in Slovene that she is an Italian. I think we young people are more conscious. (DC)

The expression of Friulian identity, as indicated by the responses of informants, is not dependent on age groups but is rather a matter of a group of intellectuals "who cultivate their own thinking" (AC, in Križman 2013: 57). The majority of informants stressed the difference between intellectuals, for whom the belonging to Friulian identity is conscious, and "ordinary people", for whom the "expression of Friulian consciousness is spontaneous, but with less political consciousness" (CP, in Križman 2013: 62); there is also a third group of people, educated Friulians, who have rejected their Friulian identity or do not recognize it publicly:

Friulian language is used today mainly in villages and rural areas by the older generation, However, this is often not a true indicator of the function of Friulian ethnic consciousness. Sociological studies are lacking and so /.../ I can rely only on my own experience. I observe two things: a sort of hidden consciousness exists that only 
comes out in circumstances of social "stress". This consciousness is present in the majority of Friulians. But there exists only a narrow circle of involved people. This last category of people is distributed transversally, perhaps somewhat more among the middle class. Young people are conscious, although they do not show this in a militant way. Intellectuals are a story of their own; they have at their disposal all the tools needed to stimulate Friulian collective identity. In most cases they have become subordinate to Italian ethnic consciousness or their behavior is ambiguous. (CP, in Križman 2013: 62).

\subsection{Which language/languages do you use in your family?}

Responses in all age groups among Slovenes and Friulians showed a broad spectrum of different idioms in use in families. In some families only the Slovene or the Friulian dialect is used, while in others each parent speaks to the children in their own language, and in one family the Italian dialect and standard Slovene are used so that the father can learn Slovene grammar, which the daughter, who attends a bilingual school, knows. In one Friulian family the father always speaks Friulian with his two now grown children, and the son responds in Friulian while the daughter understands Friulian but never uses it. His wife knows Friulian but always speaks Italian with him since that is how she spoke in her own family. Similar was the response of one of the Slovenian informants, who speaks Slovene with his wife while she speaks only Italian although she is Slovene, since that is how they spoke in her family of origin and in the school where she studied to be a teacher. The circumstances of the use of both languages may perhaps be best illustrated by the following response from a Friulian informant:

I was born in the 1970s, when language dynamics were quite different from what they are today. The Friulian language at that time was still very much alive in all the villages. However, the perception of its value was quite low. My parents spoke Friulian among themselves and also with their brothers, sisters, and parents. When I began to attend preschool and school, the teachers summoned my parents and advised them to speak Italian to the children at home so as not to hinder our 
progress in learning Italian. So my parents and other relatives (though not my grandparents) always spoke Italian with me. And I can't rid myself of this complex even today. Even if they speak to me in Friulian, I respond in Italian. This does not happen when I speak with people outside the family. Although my parents spoke to me only in Italian, I heard Friulian all around me. It was the language of my environment, my land. For this reason I got used to it. Gradually Friulian became my first language of communication. Today it is without a doubt "my language". Some thoughts can only be expressed fully in the Friulian language. (CP, in Križman 2013: 63)

\subsection{What in your opinion is the difference between the expression of Slovenian/Friulian} identity in the past and today?

As has already been mentioned in this article, older Slovene speakers see a crucial difference in that identity today is not stronger but it is expressed more openly than in the past, due to more favorable social conditions. One speaker emphasized that the crucial difference between the past and the present is that today being Slovene is accepted as something normal among young Slovenes as well as among their Italian peers:

Because what happened is, it's become normal /.../ that there is nothing wrong with being Slovene /.../ It's become normal life. Being Slovene has become a part of their life, since they had a Slovenian school, contacts with other Slovenes, and they perceive this as a normal thing. (LT)

But young Slovenes also mention that they have personally experienced humiliation as a result of expressing Slovenian identity: "Yeah, I also had problems; you know when someone said to me 'Oh, Sclâf!'”. ${ }^{10}$ However, it has not been to the same extent as that experienced by previous generations. At the same time, they observe an interest in Slovenian things among Italians, who have started to show respect towards their

\footnotetext{
${ }^{10}$ The Friulian lexeme Sclâf 'Slav' here is used with a pejorative connotation denoting 'a Slovene'.
} 
Slovenian peers and the language they speak, which is not something that could have been said for the past (at least in general):

I know a lot of people who are true Italians, not even Friulians, who want to learn Slovene, just to know another language. Lots of people say to me: 'How can I go to Kobarid ${ }^{11}$ to fill my gas tank and not know a word of Slovene.' This is my generation, 25 -year-olds. /.../ And even when we're together in a group, and we're all speaking Slovene and then you realize there's an Italian there looking at you and you say, well, and he says, no, no, keep talking, I'm thinking about that word you taught me. (IB)

The difference between the past and the present can also be seen in the many possibilities available today to learn standard Slovene in Slavia Veneta: through watching Slovenian TV, which in the past was not a given and browsing websites. One of the speakers stressed his satisfaction with how well organized Slovenian websites are, for example, the Slovenian Alpine Association, and the website of the Slovenian Environment Agency www.arso.gov.si, which is "for us like a culture from within, right, we all know about this page". (MC)

Local authorities are also aware that changes are occurring in the discursive practices of Slovenes and Friulians, and are consequently changing their own discursive practices, as observed by one of the Friulian informants:

Friulian is not much in evidence in administrative acts unless someone specifically requests it. But in everyday life many activities take place in Friulian. Today politicians also speak Friulian, something that would have been unimaginable thirty years ago. Sometimes this is just a way to gain support, but in a positive sense. Even the Friulian bishop speaks in Friulian, although he is not a Friulian. A change in mentality is happening. (WC, in Križman 2013: 58)

\footnotetext{
${ }^{11}$ Kobarid, It. Caporetto, Friul. Cjaurêt, is a settlement in western Slovenia, the administrative centre of the Municipality of Kobarid.
} 
The social ideology in which the state language is the most prestigious means of communication is changing, as the responses above indicate. ${ }^{12}$ This has led to a situation among Slovenes and Friulians that one of the Slovenian informants some years ago called a "gap between language and consciousness" (Zuljan Kumar 2003: 7), as clearly demonstrated by a Friulian informant:

In Friuli there are /.../ areas where the linguistic component is strongly present, for example Codroipo, where I'm from. There are also areas where the residents feel like Friulians even though they don't speak Friulian. These are the parts of Friuli that are close to Veneto (San Vito, Portogruaro, Sacile, etc.), and also parts near Gorizia. /.../ The situation is truly complex since a second- or third-generation emigrant who has already lost the Friulian language can feel more Friulian than someone from Udine. (WC, in Križman 2013: 58)

In many families it happens today that children can only speak Slovene/Friulian with their grandparents, since these did not teach their children their mother tongue. However, members of the middle generation nevertheless feel like Slovenes/Friulians and they therefore encourage their children to learn and use the Slovene/Friulian language. ${ }^{13}$

One of the Friulian informants sees actual changes in the attitude to Friulian in the dissipation of the discriminatory attitude towards Friulian among speakers themselves as well as among speakers of the majority Italian language, in which print and other media

12 The changed attitude of speakers towards Friulian is also confirmed by Picco's survey on the attitude of teenagers from 15 to 18 years old to the Friulian language and identity (Picco 2013). It has shown that $95,3 \%$ of the interviewees address the unknown person in Italian. But to the question, what would be their reaction, if that person answers in Friulian, $3 / 4$ of the teenagers say that that would be something normal $(76,5 \%)$, only $1,3 \%$ find the use of Friulian as an act of inappropriate behaviour (Picco 2013: 132). Similarly, the answers of the teenagers show that they no more consider those using Friulian as less successful at school comparing to those that use Italian. They also do not feel being made fun of by their schoolmates if speaking Friulian (Picco 2013: 136).

Similar results on the normality of the public use of Friulian language were obtained by the survey on the Friulian habits, attitudes, opinions, knowledge:

[i]t seems that the majority of negative stereotypes associated with the use of Friulian have disappeared over time and at the same time the strength of the "ideological" claims of those who associate the use of the language to some cultural or identity "advantage" has diminished. In 2014, iFriulian is seen as a language without connotations, be they negative or positive (Melchior 2015: 4).

${ }^{13}$ According to the survey on the Friulian habits, attitudes, opinions, knowledge and use the percentage of those interviewees who think that if both parents are Friulian they should speak to their children in Friulian in all three provinces was close to 90\% (Melchior 2015: 3). 
have an important role, in particular the internet and Radio Onde Furlane, which offers people a different view of minority languages:

In Udine today Friulian is more visible than it was a few decades ago when it was /.../ perceived as a socially 'unfit, crude' language in the town, in administrative offices, and in military barracks, perhaps suitable only for use in the pub. Twenty years ago if you went to the train station to buy a ticket and asked for information in Friulian, the clerk would respond with contempt in - frequently grammatically incorrect - Italian, since in fact Friulian was also his mother tongue. Today it is normal to ask for a ticket in Friulian and get a response in Friulian, which is most common (in my experience), or in Italian, but without a discriminatory and snobbish tone. (MS, in Križman 2013: 69)

\subsection{How do you see the future of the community to which you belong?}

Slovene speakers were optimistic in their responses, with their hope based on the work of bilingual schools whose numbers of pupils are rising, the work of music school, the activities of cultural organizations, and above all the fact that the use of Slovene in public has become something normal.

However, the majority of speakers were of the opinion that Slovenian identity in Slavia Veneta will not be preserved in the form in which we know it today. Due to different living conditions a new form of coexistence will emerge that will no longer be attached to local territory, but it will be up to social groups as to whether the use of Slovenian will be preserved in interpersonal communication or not. Namely, as contemporary trends show (and which was already typical in the past), the problem of Slavia Veneta is not the existence of a Slovenian minority but depopulation of the traditionally Slovene mountain villages, caused by high birth deficits and emigration (Steinicke et al. 2015, Josipović 2014). However, in contrast to bygone eras, when emigration flowed to more distant places in Friuli and predominantly to Belgium and France, today Slovenes from Slavia Veneta settle in Cividale or in the nearby villages in the plains such as Škrutovo/Scrutto and Špeter/San Pietro al Natisone. At the same time 
Serbs, Croatians, Macedonians, Bulgarians and Romanians are moving into abandoned villages and sending their children to Italian schools (DC, LT).

Friulians have to face the same problems as Slovenes, i.e. high emigration from mountainous villages and major changes in ethno demographic structure of the region. Namely, as the data show, that the whole region of FVG is a territory of in-migration ever since the fall of Berlin Wall (Josipović 2014: 59, Salimbeni 2014: 13). All four provinces of FVG have experienced a migratory burst in the last decade (Josipović 2014: 60) ${ }^{14}$ with the Province of Udine having the highest share of foreign population in total population of Region FVG (Josipović 2014: 60, tab. 3). ${ }^{15}$ According to that Friulians and Slovenes in FVG will need to become accustomed to living in a multicultural society, which the majority of population has not realized yet, as emphasized by a younger Slovene speaker:

And we haven't yet started to think about the fact that over time we will also become part of this multiculturalism, and now gradually it will be necessary to also think about what it even means to have a father who is Slovene, a grandfather who is Friulian, a neighbor who is Moroccan, I mean, it's not something bad, something negative, but gradually we also have to learn what it means to be part of this new society. (DC)

In contrast to Slovenes, Friulian speakers were less optimistic in their responses about the Friulian identity in the future. One speaker emphasized the need for FVG to gain the same degree of autonomy at the level of the school system as that held by Bolzano and Trento (SC, in Križman 2013: 66). Informants for the most part agreed with the assertion that the Friulian language remains marginalized in several aspects of public life (in public administration and education), and therefore, one of the crucial efforts of ARLeF as the umbrella organization for the promotion of Friulian language is to introduce

\footnotetext{
${ }^{14}$ According to the citizenship, the highest number of emigrants in FVG comes from Romania and Albania, i.e. $30 \%, 26 \%$ of emigrants come from the former Yugoslavia's successor nationalities (26\%), while the remainder of $44 \%$ is highly dispersed; $7 \%$ for former Eastern Bloc countries of Poland, Ukraine and Moldova, 5\% for Morocco and Tunisia, 5\% for Ghana, 3\% for India and $3 \%$ for PR China, and the rest for other countries (Colombia, Bangladesh etc.) (Josipović 2014: 60).

15 The data are for the year 2009.
} 
Friulian into areas that are not associated with fogolâr ${ }^{16}$ but to those areas of life in which the traditionally predominating role is held by Italian. Thus, in recent times innovative cultural elements have been offered, for example, by means of which attempts are made to get young people more involved in the Friulian language and Friulian matters. However, Friulian still needs to find its way to an important domain of life, i.e. the domain of economy and labour market, because, as Williams points out,

the ability of a language group to produce and reproduce itself rests heavily upon the extent to which the associated language enters the labor market and provides opportunities for social mobility at least within the regional labor market (Williams 2005: 1).

Thus, Friulian in the domain of economy must not only be present as an "object", i.e. at the level of denomination of the products, and isolated phrases (slogans) but as a "subject", i.e. alive and tangible - visible and audible in advertisements, signboards, instructions for the use of products, etc. (Stolfo 2014: 19-23; 27-29, Finco 2014: 29). Also, the development of some of the crucial elements of the so-called new economy (i.e. service-based economy), like linguistic technologies (that include automatic translation tools for the translation from a national to a minority language and vice versa) is still very slow, not only within the Friulian community but within many other linguistic minorities, as well (Williams 2002: 36). Furthermore, to be more visible, Friulian has to be offered beside Italian, German and English on the websites of various institutions in FVG, like the municipalities, museums, libraries. And most importantly, for the language to survive the children and teenagers should not learn ABOUT it but IN it (Coluzzi 2015: 506, 509, Picco 2013: 134). That is the only way it becomes their language of communication and not the object of learning "mere grammatical and spelling rules" (Picco 2013: 134).

${ }^{16}$ The Friulian lexeme fogolâr means 'hearth' or 'home'. 


\section{Concluding thoughts}

This study has shown that language as one of the crucial signifier of an individual's or group's identity is important for the individual's belonging in a group, but knowledge of the language alone is not enough if consciousness of group belonging is lacking. At the same time, the study has also shown that consciousness of belonging to a group is not necessarily connected with active use of the mother tongue of the community. As the responses indicate, the use of language and the feeling of belonging to the community that speaks that language are not a matter of social group but of educational level. In the past, people were not conscious of their ethnic identity or they did not emphasize it, while today, in different social conditions, speakers from Friulian community and the Slovenian community in the Province of Udine express their ethnic identity more openly than in the past, which for Slovenes can be attributed to the influence of bilingual schools and for both communities can be attributed to changed social circumstances in which the minority language is losing the status of an inferior language in comparison to Italian.

In recent years, Friulian and Slovene in the Province of Udine have become more visible and audible in public informal life, on the radio, billboards, and the internet, which informants perceive as a normalization of relations in society.

As the study has shown, Friulians and Slovenes in the Province of Udine no longer experience Italian as the sole means of communication in the sphere of public communication, which in fact implies a legitimization of their social and consequently also their political power.

In the future, efforts have to be directed towards the establishment of bilingual primary schools in the Friulian community and bilingual schooling on the secondary level in the Slovenian community as well as towards introduction of Friulian into the domain of economy, not as an object but as alive and tangible language used in spoken and written discourse in all domains of life. 
Dialectologia 24 (2020), 273-296.

ISSN: 2013-2247

\section{References}

Graduation thesis

KRIŽMAN, V. (2013) Furlanska identiteta (Friulian Identity), Graduation thesis, Nova Gorica: University of Nova Gorica.

Interviews

DC - San Pietro al Natisone, 20 February 2012

DT - San Pietro al Natisone, 20 February 2012

IB - San Pietro al Natisone, 20 February 2012

LT - Cividale, 8 February 2013

MC - San Pietro al Natisone, 20 February 2012

MN - San Pietro al Natisone, 20 February 2012

WC - Udine, 31 July 2013

Bibliography

BECK, Ulrich (2003) Kaj je globalizacija? Zmote globalizma - odgovori na globalizacijo, Ljubljana: Krtina.

BONAMORE, Daniele (2004) Lingue minoritarie, lingue nazionali, lingue ufficiali nella legge 482/1999, Milano: Franco Angeli.

CISILINO, William (2001) La tutela delle Minoranze Linguistiche. Analisi della normativa statale e regionale, con particolare riguardo alla lingua friulana, Udine: Edito dal Consorzio Universitario del Friuli.

CISILINO, William (2008) "La tutela giuridica della lingua friulana", in W. Cisilino (ed.), Friulano lingua viva. La comunità linguistica friulana, Udine: Edizione Forum.

CISILINO, William (2014) "Laws for the Protection of the Friulian Language", in R. Mucignat (ed.), The Friulian Language. Identity, Migration, Culture, Newcastle upon Tyne: Cambridge Scholars Printing, 15-27.

CISILINO, William (2015) "Il quadro giuridico", in S. Heinemann \& L. Melchior (eds.), Manuale di linguistica friulana, Berlin, Boston: De Gruyter, 475-491. 
CoLA, Tanja (2013) Porajajoča se pismenost v dvojezičnem okolju. Primer otrok, ki obiskujejo vrtce s slovenskim jezikom v Italiji in dvojezični vrtec v Špetru, Trst: SLORI.

Coluzzl, Paolo (2007) Minority Language Planning and Micronationalism in Italy. An Analysis of the Situation of Friulian, Cimbrian and Western Lombard with Reference to Spanish Minority Languages, Contemporary Studies in Descriptive Linguistics, Bern: Peter Lang.

ColuzzI, Paolo (2015) "Il friulano: confronto con altre lingue minoritarie", in S. Heinemann \& L. Melchior (eds.), Manuale di linguistica friulana, Berlin, Boston: De Gruyter, 492-510.

DAPIT, Roberto (2014) "Alcune riflessioni sul turismo culturale a Resia in relazione alle altre comunità linguistiche", in L. Negro (ed.), Lingue e turismo. Le varianti locali delle lingue minoritarie come elementi di richiamo turistico. Atti del convegno Centro Culturale "Rozajanska kulturska hïša” Ravanca/Prato di Resia (Vidan/Udine) 27 settembre 2008, Resia: Centro Culturale "Rozajanska kulturska hiša” Ravanca, 74-82.

D’ARONCO, Gianfranco \& Wiliam CISILINO (2012) Sorestants e sotans. Intervista sul Friuli, Udine: La biblioteca del Messaggero Veneto.

DuCA, Massimo (2014) "Il friulano e le sue opportunità nel turismo", in L. Negro (ed.), Lingue e turismo. Le varianti locali delle lingue minoritarie come elementi di richiamo turistico. Atti del convegno Centro Culturale "Rozajanska kulturska hïša" Ravanca/Prato di Resia (Vidan/Udine) 27 settembre 2008, Resia: Centro Culturale "Rozajanska kulturska hiša" Ravanca, 24-26.

EUROPEAN CHARTER FOR REGIONAL OR MINORITY Languages <https://www.coe.int/en/web/europeancharter-regional-or-minority-languages/home>

FAKIN BAJEC, Jasna (2016) "Cultural heritage and the Role of Voluntary Associations in the Process of Achieving Sustainable Development in Rural Communities", Studia ethnologica Croatica, 28, 21-45.

FINCO, Franco (2014) “Lingua friulana e marketing nell'offerta turistica”, in L. Negro (ed.), Lingue e turismo. Le varianti locali delle lingue minoritarie come elementi di richiamo turistico. Atti del convegno Centro Culturale "Rozajanska kulturska hï̌a" Ravanca/Prato di Resia (Vidan/Udine) 27 settembre 2008, Resia: Centro Culturale "Rozajanska kulturska hiša" Ravanca, 27-30.

FISHMAN, Joshua Aaron (2001) Can Threatened Languages Be Saved?, Clevedon, UK: Multilingual Matters. 
GarCíA, Ofelia (2010) "Languaging and Ethnifying", in J. A. Fishman \& O. García (eds.), Language and Ethnic Identity. Volume I. Disciplinary and Regional Perspectives, Oxford: Oxford University Press, 519-533.

HARVEY, David Allen (2001) Constructing Class and Nationality in Alsace 1830-1945, DeKalb: Northern Illinois University Press.

Heinemann, Sabine (2015) “Tergestino/Muglisano", in S. Heinemann \& L. Melchior (eds.), Manuale di linguistica friulana, Berlin, Boston: De Gruyter, 226-244.

HelleR, Monica (1999) Linguistic Minorities and Modernity. A Sociolinguistic Ethnography, London: Longman.

IANNÀcCARO, Gabriele \& Vittorio Dell'Aquila (2015) "La situazione sociolinguistica", in S. Heinemann \& L. Melchior (eds.), Manuale di linguistica friulana, Berlin, Boston: De Gruyter, 453-474.

JosIPOVIĆ, Damir (2014) "Recent Demographic Trends in the Northern Borderland between Italy and Slovenia: Stabilization or Further Redistribution of Population?", European Countryside, $12014,50-67$.

LE PAGE, Robert \& Andrea TABOURET-KelleR (1985) Acts of Identity: Creole-Based Approaches to Language and Ethnicity, Cambridge UK: Cambridge University Press.

MARANGON, Francesco (2002) “Un'analisi economica della promozione della cultura e della lingua friulana nella regione Friuli-Venezia Giulia", in W. Cisilino (ed.), Lingue minoritarie e identità locali come risorse economiche e fattori di sviluppo. Atti del convegno internazionale Udine, 8-9 novembre 2002, Udine: Forum, 83-99.

MELCHIOR, Claudio (2015) Survey and statistical analysis on the Friulian habits, attitudes, opinions, knowledge and use, Udine: ARLeF, Università di Udine. <http://www.arlef.it/en/friulianlanguage/sociolinguistic-condition/5\#/sociolinguistic-condition;litalian>

MeZgeC, Maja (2016) "Linguistic Landscape as a Mirror: the Case of the Slovene Minority in Italy", Razprave in gradivo $77,67-85$.

PADILlA, Amado \& Graciela BORSATO (2010) "Disciplinary and Methodological Approaches: Psychology", in J. A. Fishman \& O. García (eds.), Language and Ethnic Identity. Volume I Disciplinary and Regional Perspectives, Oxford: Oxford University Press, 5-16.

PERTOT, Suzana \& Marianna KOSIC (2014) Jeziki in identitete $v$ precepu. Mišljenje, govor in predstave o identiteti pri treh generacijah maturantov šol s slovenskim učnim jezikom $v$ Italiji, Trst: SLORI. 
PICco, Linda (2008) "La condizione sociolinguistica del friulano", in W. Cisilino (ed.), Friulano lingua viva, Udine: Forum, Editrice Universitaria Udinese srl., 143-171.

PICco, Linda (2013) "I giovani e la lingua friulana: appartenenza ed identità linguistica tra i ragazzi dai 15 ai 18 anni in Friuli", in L. Picco (ed.), Lingua friulana e società: studi sociolinguistici sul Friuli di oggi, Udine: Forum, 113-159.

PICco, Linda (2014) "Lingua friulana: alcuni studi in merito alla sua vitalità e diffusione", in V. Porcellana \& F. Diémoz (eds.), Minoranze in mutamento. Etnicità, lingue e processi demografici nelle valli alpine italiane. Mondi locali, villaggi globali. Collana di antropologia culturale, Alessandria: Edizioni dell'Orso. Pages?

POSSENTI, Damiano (2002) “Il marketing dei prodotti vicini alla loro terra d'origine: Sans Souci e la lingua friulana", in W. Cisilino (ed.), Lingue minoritarie e identità locali come risorse economiche e fattori di sviluppo. Atti del convegno internazionale Udine, 8-9 November 2002, Udine: Forum, 137-142.

PRESTON, Peter Wallace (1997) Political/Cultural Identity. Citizens and Nations in a Global Era, London: Sage Publications.

QUAGLIA, Sandro (2014) "Le esperienze di turismo linguistico in Val Resia (Udine)", in L. Negro (ed.), Lingue e turismo. Le varianti locali delle lingue minoritarie come elementi di richiamo turistico. Atti del convegno Centro Culturale "Rozajanska kulturska hïša" Ravanca/Prato di Resia (Vidan/Udine), 27 settembre 2008, Resia: Centro Culturale "Rozajanska kulturska hiiša", Ravanca, 68-71.

RoSA, Franco (2002) "Differenziazioni, culture locali e atteggiamenti del consumatore", in W. Cisilino (ed.), Lingue minoritarie e identità locali come risorse economiche e fattori di sviluppo. Atti del convegno internazionale Udine, 8-9 novembre 2002, Udine: Forum, 100125.

ROSEANO, Paolo (1999) Identità friulana. Così è e così I'hanno prodotta i miti, i parroci, le élite locali, Gorizia: ISIG.

RoSEANO, Paolo (2002) "Patriarchi e preti: l'elemento religioso nell'identità etnica friulana", Annales. Series historia et sociologia, 12/2002/2, 331-340.

SALIMBENI, Fulvio (2014) "History, Language and Society in Friuli (Thirty years Later)", in R. Mucignat (ed.), The Friulian Language. Identity, Migration, Culture, Newcastle upon Tyne: Cambridge Scholars Publishing, 2-14.

SILLANI, Sandro (2002) "La comunicazione di marketing in friulano: il caso dell'Iperlavoratore", in W. Cisilino (ed.), Lingue minoritarie e identità locali come risorse economiche e fattori di 
sviluppo. Atti del convegno internazionale Udine, 8-9 novembre 2002, Udine: Forum, 185196.

STEINICKE, Ernst, Igor JELEN, Karl Gerhard LIEB, Roland LÖFFLER \& Peter ČEDE (2016) "Slovenes in Italy: a Fragmented Minority", European Countryside, 1, 49-66.

Stolfo, Marco (2014) "Lingue di minoranza e promozione del territorio: oggetto, soggetto, opportunità", in L. Negro (ed.), Lingue e turismo. Le varianti locali delle lingue minoritarie come elementi di richiamo turistico. Atti del convegno Centro Culturale "Rozajanska kulturska hïša" Ravanca/Prato di Resia (Vidan/Udine) 27 settembre 2008, Resia: Centro Culturale "Rozajanska kulturska hïša”, Ravanca, 11-23.

Stolfo, Marco \& Claudio CRESSATI (2016) Cercare il Friuli e trovare I'Europa. La minoranza linguistica friulana e la sua tutela: rivendicazioni, normative, politiche e problemi, Udine: Forum.

STRASSOLDO, Raimondo (1996) Lingua, identità, autonomia, Ricerche e riflessioni sociologiche sulla questione friulana, Campoformido: Ribis.

STRASSOLDO, Raimondo (2002) "Aspetti socio-economici della dinamica linguistico-culturale in Friuli", in W. Cisilino (ed.), Lingue minoritarie e identità locali come risorse economiche $e$ fattori di sviluppo. Atti del convegno internazionale Udine, 8-9 novembre 2002, Udine: Forum, 67-75.

SusıČ, Emidij, Adriana JANEŽIč \& Feliciano MEDEOT (2010) Indagine sulle comunità linguistiche del Friuli Venezia Giulia. Tutela e normativa, Udine: Regione autonoma Friuli Venezia Giulia, Direzione centrale istruzione, formazione e cultura, Servizio identità linguistiche, culturali e corregionali all'estero.

ŠABEC, Ksenija (2006) Homo europeus: nacionalni stereotipi in kulturna identiteta Evrope, Ljubljana: Fakulteta za družbene vede.

VASSBERG, Liliane (1993) Alsatian Acts of Identity. Language Use and Language Attitudes in Alsace, Cleveland, Philadelphia, Adelaide: Multilingual Matters LTD.

VIDAU, Zaira (2012) “Unresolved Questions Concerning the Public Use of Minority and Regional Languages in Interactions between Municipal and Provincial Administrations and the Public in the Region of Friuli-Venezia Giulia in Italy 2", European yearbook of minority issues, 11, 143-166.

VIDAU, Zaira (2013) "The Legal Protection of National and Linguistic Minorities in the Region of Friuli-Venezia Giulia: A Comparison of the Three Regional Laws for Slovene Linguistic 
Minority, for the Friulian Language and for German-speaking Minorities", Treatises and Document, Journal of Ethnic Studies, Revija za narodnostna vprašanja, 12/2013, 27-52.

VIDAU, Zaira (2015a) "Intercultural Relations between the Slovene National Minority and the Majority Population in Italy after the Independence of Slovenia", Research in social change 7 (3), 283-317.

VIDAU, Zaira (2015b) "The Public use of Minority and Regional Languages in the local Administrations of the Friuli Venezia Giulia Region in Italy", in B. Schrammel-Leber \& C. Korb (eds.), Dominated Languages in the 21st Century: papers from the International conference on minority languages XIV (Grazer Plurilingualismus Studien, 1), Graz: KarlFranzens-Universität, 68-83.

WILlIAMS, Glyn (2002) "Lingua e new economy", in W. Cisilino (ed.), Lingue minoritarie e identità locali come risorse economiche e fattori di sviluppo. Atti del convegno internazionale Udine, 8-9 novembre 2002, Udine: Forum, 33-37.

WILlaAMS, Glyn (2005) Multimedia, Minority Languages and the New Economy. <http://www.gencat.cat/llengua/noves/noves/hm05hivern/docs/williams.pdf>

Zaščitni zakon za Slovence $v$ Italiji. Zakon 38/2001. <http://www.slovenskaskupnost.org/downloads/2\%20-\%20Zakon\%2038-2001.pdf>

Zakon 38/2001. Norme per la tutela della minoranza linguistica slovena della regione Friuli Venezia Giulia.

ZULAN KUMAR, Danila (2003) "Vloga narečja v družbi danes in jutri”, Primorska srečanja, 27/263, 2-11.

ZULAN KUMAR, Danila (2011) "Jezik, skupnost, identiteta: odnos do prvega (maternega) jezika v času globalizacije (primer Beneških Slovencev in Furlanov)", Goriški letnik, 35, 229-242.

ZUUAN KUMAR, Danila (2016) "Narodna identiteta pri Beneških Slovencih in Furlanih danes", Jezik in slovstvo, 2/2016, 7-18.

ZULAN KUMAR, Danila (2018) "Identity Changes in the Slovenian and Friulian Linguistic Communities in The Province of Udine, Friuli-Venezia Giulia", Italy, European Countryside (in print).

ŽABJEK-SCUTERI, SAŠA (1987) “Furlani na razpotju”, Goriški letnik, 12/14, 205-228. 